\title{
PRODUKSI KARET SIR 20CV MENGGUNAKAN FORMULA HIDRAZIN HIDRAT DAN AMMONIUM SULFAT SEBAGAI ADITIF
}

\author{
THE PRODUCTION OF RUBBER SIR 20CV USE HYDRAZINE HYDRATE \\ AND AMMONIUM SULFATE FORMULA AS ADDITIVE
}

\author{
Afrizal Vachlepi \\ Balai Penelitian Sembawa - Pusat Penelitian Karet \\ Jl. Raya Palembang-Pangkalan Balai Km.29 Sembawa \\ Kotak Pos 1127 Palembang 30001 Sumatera Selatan \\ e-mail: a_vachlepi@yahoo.com
}

Diterima: 15 Nopember 2017 ; Direvisi: 13 Desember 2017 - 11 Juni 2018; Disetujui: 28 Juni 2018

\begin{abstract}
Abstrak
Produk utama karet alam Indonesia adalah SIR 20. Peningkatan mutu dapat dilakukan dengan mengubah produksi karet alam SIR 20 menjadi SIR 20 viskositas mantap (SIR 20CV). Produksi karet alam SIR 20CV memerlukan bahan pemantap antara lain campuran hidrazin hidrat dan ammonium sulfat. Tujuan penelitian ini adalah untuk mengetahui dan mempelajari formulasi dan dosis penggunaan dari campuran bahan aditif hidrazin hidrat dan ammonium sulfat dalam produksi karet alam viskositas mantap. Penelitian ini menggunakan rancangan acak lengkap (RAL) faktorial dengan faktor perlakuan terdiri dari persentase campuran hidrazin hidrat dan ammonium sulfat (perlakuan A) dan dosis penggunaan aditif (perlakuan B) serta kontrol (HNS dan blanko/tanpa aditif). Perlakuan A terdiri dari 50\%:50\% (A1), $70 \%: 30 \%$ (A2) dan 30\%:70\% (A3). Perlakuan B terdiri dari 0,05\% (B1), 0,10\% (B2), 0,15\% (B3) dan 0,20\% (B4). Parameter yang diamati berupa kondisi penggumpalan lateks, kadar karet kering (KKK) dan mutu teknis (plastisitas awal/Po, indeks ketahanan plastisitas/PRI, viskositas Mooney/MV, indeks kestabilan viskositas/SVI, kadar zat menguap dan kadar abu). Analisa mutu teknis dibandingkan dengan persyaratan mutu Standar Nasional Indonesia (SNI) 061903-2000 tentang Standard Indonesian Rubber (SIR). Hasil penelitian menunjukkan bahwa penggunaan bahan aditif campuran hidrazin hidrat dan ammonium sulfat berpengaruh nyata pada parameter $\mathrm{pH}$ penggumpalan lateks, kadar karet kering, Po, PRI, viskositas Mooney dan SVI dari karet alam SIR 20CV yang dihasilkan. Perlakuan terbaik dihasilkan oleh perlakuan A3B1 yaitu perbandingan $30 \%$ hidrazin hidrat dan $70 \%$ ammonium sulfat dengan dosis 0,05\%. Perlakuan A3B1 dapat menghasilkan karet alam SIR 20CV dengan grade CV-70 sesuai dengan SNI 06-1903-2000.
\end{abstract}

Kata kunci: ammonium sulfat, hidrazin hidrat, mutu, SIR 20CV

\begin{abstract}
The main product of Indonesia natural rubber is SIR 20. The quality improvement can be done by converting the production of natural rubber SIR 20 to SIR 20 constant viscosity (SIR 20CV). The production of natural rubber SIR 20CV need the stabilizing agents among other a mixture of hydrazine hydrate and ammonium sulfate. The research purpose was to find out and to study the formulation and dosage of the mixture hydrazine hydrate and ammonium sulfate on the production of constant viscosity rubber. This research used factorial completely randomized design with the treatment factor consist of percentage of mixture hydrazine hydrate-ammonium sulfate (treatment $A$ ), additive dosage (treatment $B$ ) and control (HNS and blank/without additive). The treatment $A$ consists of 50\%:50\% (A1), 70\%:30\% (A2), and 30\%:70\% (A3). The treatment $B$ consists of $0.05 \%$ (B1), $0.10 \%$ (B2), $0.15 \%$ (B3) and $0.20 \%$ (B4). Parameters were latex coagulation condition, dry rubber content, and technical quality (initial plasticity/Po, plasticity retention index/PRI, Mooney viscosity/MV, stability viscosity index/SVI, volatile content and ash content). The analysis of technical quality was compared with requirements of SNI 06-1903-2000 about SIR. The results showed that the use of mixed additives of hydrazine hydrate and ammonium sulfate had a significant effect on the parameter $\mathrm{pH}$ of latex coagulation, dry rubber content, plasticity, Mooney viscosity, and viscosity stability index of the rubber SIR $20 \mathrm{CV}$. The best treatment was obtained by the treatment of A3B1, which is $30 \%$ hydrazine hydrate and $70 \%$ ammonium sulfate with a dosage of $0.05 \%$, because could produce natural rubber SIR $20 \mathrm{CV}$ with grade CV70 in accordance with SNI 06-1903-2000.
\end{abstract}

Keywords : ammonium sulfate, hydrazine hydrate, quality, SIR 20CV 


\section{PENDAHULUAN}

Ekspor karet alam Indonesia pada tahun 2015 sekitar 3,1 juta ton (Direktorat Jenderal Perkebunan, 2015). Angka ini menunjukkan bahwa karet alam merupakan salah satu komoditi penting dan strategis bagi Indonesia. Produk ekspor utama karet alam Indonesia masih berupa karet SIR 20 yang mencapai $95 \%$ dari total ekspor. Tingginya jumlah ekspor karet SIR 20 ini lebih disebabkan bahan olah karet (bokar) yang digunakan berasal dari koagulum karet rakyat (petani). Hasil survei yang dilakukan Syarifa et al. (2013) di Sumatera Selatan sebagai provinsi penghasil karet alam terbesar di Indonesia mendapatkan bahwa mutu bokar petani masih belum baik. Sebagian petani masih mencampurkan kontaminan seperti tatal (kulit kayu sadapan) ke dalam bokar. Selain itu, masih banyak ditemukan petani yang menggunakan bahan penggumpal (koagulan) yang tidak direkomendasi.

Sayangnya, di dalam standar mutu yang tercantum dalam Standar Nasional Indonesia (SNI) 06-1903-2000 tentang Standard Indonesian Rubber (SIR), karet SIR 20 termasuk dalam karet spesifikasi teknis yang bermutu rendah. Oleh karena itu perlu peningkatan mutu karet Indonesia sehingga ke depannya persentase karet SIR 20 yang diekspor berkurang dan digantikan dengan karet yang mutunya lebih baik. Salah satu cara meningkatkan mutu karet SIR 20 adalah dengan mengubahnya menjadi karet SIR 20CV (constant viscosity) atau karet SIR 20VK (viskositas konstan/mantap). Karet SIR 20CV adalah karet alam standar SIR 20 yang nilai viskositasnya stabil atau mantap.

Permintaan karet alam SIR $20 \mathrm{CV}$ diprediksi akan terus mengalami peningkatan. Pabrik ban sebagai konsumen utama karet alam sebagian sudah mulai mengurangi penggunaan energi. Dalam industri pengolahan karet alam termasuk pabrik pembuatan ban, energi menjadi faktor penting yang berpengaruh terhadap biaya produksi.
Salah satu tahapan proses yang harus dilakukan dalam pembuatan ban adalah proses mastikasi karet alam. Proses mastikasi perlu dilakukan pada saat pembuatan kompon karet alam (Daik et al, 2007) sebelum dicetak menjadi ban.

Penggunaan karet viskositas mantap, seperti karet SIR 20CV, dapat mempersingkat waktu proses mastikasi sehingga berdampak pada menurunnya konsumsi energi. Solichin dan Immanuel (1991) menyatakan bahwa energi yang dibutuhkan untuk proses mastikasi ini sebesar $33-35 \%$ dari total energi pada saat pembuatan kompon karet. Dengan berkurangnya proses mastikasi, konsumsi energi juga menjadi lebih rendah sehingga lebih efisien dan dapat mengurangi biaya produksi (Vachlepi dan Suwardin, 2015a).

Dalam pembuatan karet viskositas mantap SIR 20CV diperlukan bahan aditif yang berfungsi mencegah terjadinya reaksi ikatan silang yang menyebabkan pengerasan selama proses penyimpanan (storage hardening) (Vachlepi dan Suwardin, 2015a). Reaksi ikatan ini terjadi secara alami yang ditandai dengan kenaikan nilai viskositas Mooney. Solichin (1995) menyatakan bahwa mekanisme proses storage hardening adalah terjadinya ikatan silang gugus aldehida pada rantai poliisoprena (Gambar 1).

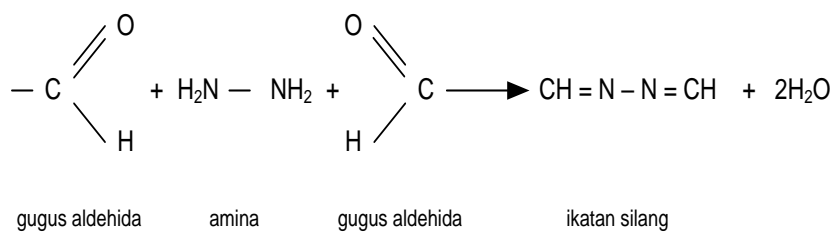

Gambar 1. Mekanisme reaksi ikatan silang penyebab terjadinya storage hardening

Vachlepi et al. (2014) menyatakan kelompok hidrazin hidrat merupakan salah satu aditif yang dapat digunakan sebagai bahan pemantap karet alam. Senyawa hidrazin hidrat berfungsi sebagai pendonor gugus hidrogen yang dapat mereduksi ikatan 
rangkap molekul karet alam menjadi ikatan tunggal (jenuh) (Rahman et al., 2002) melalui reaksi hidrogenasi (Sa et al., 2004). Penggunaan hidrazin hidrat sebagai bahan pemantap mempunyai keuntungan lain, yaitu tingkat korosi yang lebih rendah dibandingkan HNS (hidroksilamin netral sulfat) yang sudah umum digunakan. HNS termasuk bahan kimia yang bersifat korosi terhadap baja karbon dengan kategori ketahanan korosi mulai dari buruk sampai cukup (Vachlepi dan Suwardin, 2016).

Walaupun menghasilkan karet alam dengan nilai viskositas yang stabil atau konstan, tetapi nilai viskositas tersebut masih tergolong besar atau tinggi. Beberapa pembeli karet alam, selain viskositas mantap juga menginginkan nilai viskositas yang rendah. Untuk mendapatkan karet alam yang mempunyai nilai viskositas rendah (low viscosity) juga memerlukan penambahan bahan aditif. Senyawa kimia yang dapat digunakan untuk menurunkan nilai viskositas karet alam antara lain kelompok garam ammonium, seperti ammonium sulfat (Vachlepi dan Suwardin, 2015b).

Perpaduan senyawa kimia hidrazin hidrat dan ammonium sulfat diprediksi dapat menghasilkan karet alam 20CV. Penelitian mengenai formulasi dan dosis penggunaan kedua bahan aditif masih belum dilakukan terutama mengenai formulasi dan dosis penggunaannya. Adapun tujuan penelitian ini adalah untuk mengetahui dan mempelajari formulasi dan dosis penggunaan dari campuran bahan aditif hidrazin hidrat dan ammonium sulfat dalam produksi karet alam viskositas mantap.

\section{BAHAN DAN METODE}

\section{Bahan}

Penelitian ini dilakukan di Laboratorium Teknologi Pengolahan Balai Penelitian Sembawa. Bahan yang digunakan berupa lateks segar dari klon karet PB 260 yang diperoleh dari kebun riset Balai Penelitian Sembawa, hidrazin hidrat (Merck), ammonium sulfat (Merck), $\mathrm{P}_{2} \mathrm{O}_{5}$ (Merck), asam format teknis $94 \%$, kertas lakmus dan HNS teknis.

\section{Peralatan}

Peralatan yang digunakan antara lain bak penggumpal, gelas ukur, neraca (timbangan) merek OHAUS kapasitas 2 $\mathrm{kg}$, gilingan terbuka kapasitas $1 \mathrm{~kg}$ per jam, plastimeter Wallace MK II, Mooney viskometer merek SPRI Limited SP 53, oven Memmert kapasitas 80 liter, mesin creeper kapasitas $300 \mathrm{~kg}$ per jam dan muffle furnace (Sybron/Thermolyne).

\section{Metode Penelitian}

Penelitian ini menggunakan rancangan acak lengkap (RAL) faktorial dengan faktor perlakuan terdiri dari persentase campuran hidrazin hidrat dan ammonium sulfat (perlakuan $A$ ), dosis penggunaan aditif (perlakuan $B$ ) serta kontrol (HNS dan blanko/tanpa aditif). Perlakuan A terdiri dari 50\%:50\% (A1), 70\%:30\% (A2) dan 30\%:70\% (A3). Perlakuan B terdiri dari $0,05 \%$ (B1), 0,10\% (B2), 0,15\% (B3) dan 0,20\% (B4). Total perlakuan yang diberikan berjumlah 14 perlakuan (Tabel 1). Hasil analisa statistik akan dilanjutkan dengan uji jarak berganda Duncan (DMRT).

Parameter yang diamati berupa kondisi penggumpalan lateks $(\mathrm{pH}$ dan waktu penggumpalan), kadar karet kering $(\mathrm{KKK})$ dan mutu teknis. Analisa mutu teknis terdiri plastisitas awal (Po), indeks ketahanan plastisitas (plasticity retention index/PRI), viskositas Mooney (MV), indeks kestabilan viskositas/SVI, kadar zat menguap dan kadar abu. Hasil analisa mutu teknis selanjutnya dibandingkan dengan persyaratan mutu Standar Nasional Indonesia (SNI) 061903-2000 tentang Standard Indonesian Rubber (SIR) seperti yang tercantum pada Tabel 2. Kadar karet kering karet dihitung menggunakan persamaan sebagai berikut :

$$
K K K=\frac{b}{a} \times 100 \% \quad \ldots . .(1)
$$


dimana :

$$
\begin{aligned}
K K K= & \text { kadar karet kering }(\%) \\
a \quad= & \text { bobot basah koagulum karet } \\
& \text { (gram) } \\
b \quad= & \text { bobot kering karet (gram) }
\end{aligned}
$$

Tabel 1. Perlakuan yang diberikan terhadap karet alam

\begin{tabular}{ccc}
\hline \multicolumn{2}{c}{ Perlakuan } & \\
\cline { 1 - 2 } $\begin{array}{c}\text { Perbandingan } \\
\text { Hidrazin Hidrat dan } \\
\text { Ammonium Sulfat }\end{array}$ & Dosis (\%) & \\
\hline $50 \%: 50 \%$ (A1) & $0,05(\mathrm{~B} 1)$ & A1B1 \\
& $0,10(\mathrm{~B} 2)$ & A1B2 \\
& $0,15(\mathrm{~B} 3)$ & A1B3 \\
$70 \%: 30 \%$ (A2) & $0,20(\mathrm{~B} 4)$ & A1B4 \\
& $0,05(\mathrm{~B} 1)$ & A2B1 \\
& $0,10(\mathrm{~B} 2)$ & A2B2 \\
& $0,15(\mathrm{~B} 3)$ & A2B3 \\
$30 \%: 70 \%$ (A3) & $0,20(\mathrm{~B} 4)$ & A2B4 \\
& $0,05(\mathrm{~B} 1)$ & A3B1 \\
& $0,10(\mathrm{~B} 2)$ & A3B2 \\
& $0,15(\mathrm{~B} 3)$ & A3B3 \\
HNS (kontrol) & $0,20(\mathrm{~B} 4)$ & A3B4 \\
Blanko (kontrol) & 0,15 & K1 \\
& 0,00 & K2 \\
\hline
\end{tabular}

Tabel 2. Persyaratan mutu SNI 06-1903-2000

\begin{tabular}{lcc}
\multicolumn{3}{c}{ Standard Indonesian Rubber (SIR) } \\
\hline $\begin{array}{l}\text { Spesifikasi / (asal } \\
\text { bahan olah) }\end{array}$ & $\begin{array}{c}\text { SIR 3 CV } \\
\text { lateks }\end{array}$ & $\begin{array}{c}\text { SIR 20 } \\
\text { koagulum }\end{array}$ \\
\hline $\begin{array}{l}\text { Kadar kotoran,\% } \\
\text { Maks (b/b) }\end{array}$ & 0,03 & 0,20 \\
$\begin{array}{l}\text { Kadar abu, \% Maks } \\
\text { (b/b) }\end{array}$ & 0,50 & 1,00 \\
$\begin{array}{l}\text { Kadar zat menguap, } \\
\% \text { Maks (b/b) }\end{array}$ & 0,80 & 0,80 \\
$\begin{array}{l}\text { PRI, Min } \\
\text { Po, Min }\end{array}$ & 60 & 50 \\
$\begin{array}{l}\text { Nitrogen (N), Maks } \\
\text { (b/b) }\end{array}$ & - & 30 \\
$\begin{array}{l}\text { ASHT (Satuan } \\
\text { Palastistas Wallace), } \\
\text { Maks }\end{array}$ & 0,60 & 0,60 \\
Viskositas Mooney & 8 & - \\
MI(1+4)100 & $*$ & \\
\hline
\end{tabular}

*) Tanda pengenal tingkatan:

$\mathrm{CV}-50$

Batasan viskositas

CV -60

mooney:

CV -70

$45-55$

$55-65$

$65-75$

Sumber : BSN, 2000.

\section{Pelaksanaan Penelitian}

Penelitian ini diawali dengan menyiapkan larutan konsentrasi $10 \%$ bahan aditif campuran hidrazin hidrat 4 dan ammonium sulfat serta HNS sebagai bahan aditif kontrol. Setelah itu disiapkan lateks segar dengan total sebanyak 28 liter untuk 14 perlakuan atau 2 liter per perlakuan. Lateks 2 liter tersebut dimasukkan ke dalam bak penggumpal yang selanjutnya ditambahkan bahan aditif sesuai dengan perlakuan dan diaduk hingga tercampur sempurna.

Untuk perlakuan kontrol blanko, lateks tidak dilakukan penambahan bahan aditif.Tahap berikutnya, lateks yang sudah ditambahkan bahan aditif digumpalkan dengan menggunakan koagulan asam format $2 \%$ dengan dosis $60 \mathrm{ml}$ per liter lateks. Setiap bak penggumpal yang berisi 2 liter lateks ditambahkan asam format $2 \%$ masingmasing $120 \mathrm{ml}$ per bak. Parameter $\mathrm{pH}$ dan waktu penggumpalan diamati selama proses penggumpalan.

Lateks yang sudah ditambahkan koagulan didiamkan selama 24 jam agar menggumpal secara sempurna. Lateks yang sudah menggumpal biasa disebut koagulum. Tahap terakhir, koagulum digiling menggunakan mesin creeper menjadi blanket dan dikeringkan di dalam oven bersuhu $\pm 105{ }^{\circ} \mathrm{C}$ sampai karet kering. Pada tahap ini, parameter kadar karet kering dihitung menggunakan persamaan (1). Karet yang sudah kering selanjutnya dianalisa mutu teknisnya.

\section{HASIL DAN PEMBAHASAN}

\section{Kondisi Penggumpalan}

Hasil pengamatan kondisi penggumpalan lateks dengan berbagai bahan aditif dan dosis penggunaan ditampilkan pada Tabel 3. Parameter kondisi penggumpalan yang dipelajari dari penelitian ini berupa $\mathrm{pH}$ (derajat keasamaan) dan waktu proses penggumpalan lateks menjadi koagulum. Dari hasil analisa statistik diketahui bahwa hanya parameter $\mathrm{pH}$ penggumpalan yang secara signifikan dipengaruhi oleh perlakuan yang diberikan (Tabel 3). Lateks yang ditambahkan formula bahan aditif campuran hidrazin hidrat dan ammonium 
sulfat (perlakuan A) secara umum mempunyai $\mathrm{pH}$ penggumpalan yang lebih tinggi dibandingkan lateks perlakuan kontrol terutama lateks tanpa aditif/blanko (K2). Dejarat keasaman lateks yang diberikan bahan aditif campuran hidrazin hidrat dan ammonium sulfat pada semua dosis penggunaan berkisar antara 4,75-4,90. Angka ini tidak berbeda nyata dengan lateks yang ditambahkan aditif HNS (K1). Sedangkan $\mathrm{pH}$ paling rendah diperoleh lateks yang tidak ditambahkan bahan aditif (K2) yaitu 4,70 .

Tabel 3. Kondisi penggumpalan lateks dengan berbagai perlakuan

\begin{tabular}{ccc}
\hline \multirow{2}{*}{$\begin{array}{c}\text { Kode } \\
\text { Perlakuan }\end{array}$} & \multicolumn{2}{c}{ Kondisi Penggumpalan } \\
\cline { 2 - 3 } & $\mathrm{pH}$ & $\begin{array}{c}\text { Waktu } \\
\text { (menit.detik) }\end{array}$ \\
\hline A1B1 & $4,80 \mathrm{ab}$ & $09.08^{\prime} \mathrm{a}$ \\
A1B2 & $4,80 \mathrm{ab}$ & $08.46^{\prime} \mathrm{a}$ \\
A1B3 & $4,80 \mathrm{ab}$ & $08.35^{\prime} \mathrm{a}$ \\
A1B4 & $4,80 \mathrm{ab}$ & $08.40^{\prime} \mathrm{a}$ \\
A2B1 & $4,75 \mathrm{ab}$ & $08.38^{\prime} \mathrm{a}$ \\
A2B2 & $4,80 \mathrm{ab}$ & $09.18^{\prime} \mathrm{a}$ \\
A2B3 & $4,80 \mathrm{ab}$ & $08.51^{\prime} \mathrm{a}$ \\
A2B4 & $4,90 \mathrm{a}$ & $09.25^{\prime} \mathrm{a}$ \\
A3B1 & $4,75 \mathrm{ab}$ & $09.34^{\prime} \mathrm{a}$ \\
A3B2 & $4,80 \mathrm{ab}$ & $09.11^{\prime} \mathrm{a}$ \\
A3B3 & $4,75 \mathrm{ab}$ & $09.12^{\prime} \mathrm{a}$ \\
A3B4 & $4,85 \mathrm{ab}$ & $09.32^{\prime} \mathrm{a}$ \\
K1 & $4,75 \mathrm{ab}$ & $08.33^{\prime} \mathrm{a}$ \\
K2 & $4,70 \mathrm{~b}$ & $09.23^{\prime} \mathrm{a}$ \\
\hline
\end{tabular}

Ket : angka-angka yang diikuti huruf yang sama pada setiap baris berarti tidak berbeda pada uji lanjutan Jarak Berganda Duncan (DMRT) pada tingkat kepercayaan 95\% (á $=0,05)$

Tingginya $\mathrm{pH}$ semua perlakuan penambahan bahan aditif terjadi karena bahan aditif yang ditambahkan ke dalam lateks, baik campuran hidrazin hidrat dan ammonium sulfat maupun HNS, bersifat basa sehingga akan meningkatkan $\mathrm{pH}$ penggumpalan menjadi lebih tinggi (di atas 4,70). Penggumpalan atau koagulasi lateks merupakan peristiwa perubahan fase sol menjadi fase gel yang biasanya dilakukan dengan penambahan bahan penggumpal (koagulan). Penggumpalan lateks dapat terjadi karena penurunan muatan listrik atau dehidratasi yang diakibatkan penurunan $\mathrm{pH}$ lateks (Abednego, 1981). Hasil analisa statistik menunjukkan bahwa waktu proses penggumpalan tidak dipengaruhi oleh perlakuan yang diberikan (Tabel 3). Tidak adanya perbedaan yang signifikan pada waktu penggumpalan ini disebabkan oleh penggunaan koagulan yang sama, yaitu asam format. Waktu penggumpalan lateks tercepat ditunjukkan pada perlakuan menggunakan bahan aditif HNS (K1), yaitu sekitar 8 menit 33 detik. Sedangkan waktu terlama pada perlakuan A3B1, yaitu 9 menit 34 detik.

\section{Kadar Karet Kering}

Hasil analisa kadar karet kering (KKK) menggunakan persamaan (1) disajikan pada Gambar 1. KKK adalah persentase kandungan partikel karet alam (poliisoprena) yang terdapat pada bahan olah karet dalam hal ini koagulum lateks yang sudah ditambahkan perlakuan bahan aditif. KKK merupakan istilah yang sudah umum digunakan dalam industri pengolahan karet alam (Kumar et al., 2007).

Seperti terlihat pada Gambar 1, perlakuan yang diberikan pada penelitian ini memberikan pengaruh yang signifikan terhadap kadar karet kering (KKK) koagulum lateks. KKK pada koagulum perlakuan penambahan bahan aditif campuran hidrazin hidrat-ammonium sulfat pada berbagai dosis penggunaan secara umum lebih rendah dibandingkan kontrol, baik perlakuan HNS maupun blanko/tanpa bahan aditif. Hasil perhitungan menggunakan persamaan (1) menunjukkan bahwa KKK koagulum yang ditambahkan campuran bahan aditif hidrazin hidrat dan ammonium sulfat (perlakuan A) berkisar antara 41,98\%$43,35 \%$. Sedangkan koagulum kontrol, baik HNS (K1) maupun tanpa penambahan aditif (K2), mempunyai KKK lebih dari $45 \%$. 


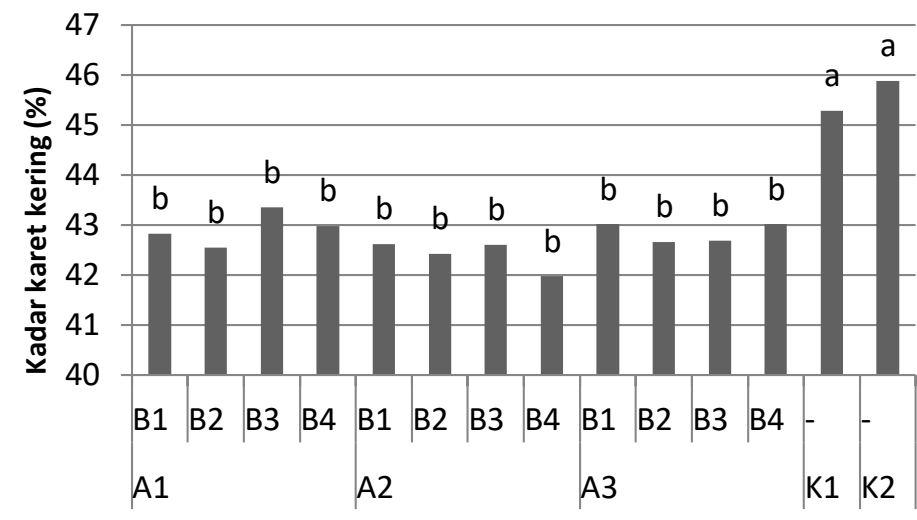

Perlakuan formula aditif dan dosis penggunaan

\section{Gambar 1. Kadar karet kering koagulum} lateks pada berbagai perlakuan

Ket : angka-angka yang diikuti huruf yang sama pada setiap baris berarti tidak berbeda pada uji lanjutan Jarak Berganda Duncan (DMRT) pada tingkat kepercayaan 95\% (á = 0,05)

Rendahnya KKK koagulum yang ditambahkan bahan aditif (KKK berkisar antara 41,98-43,35\%) terutama perlakuan campuran hidrazin hidratammonium sulfat terjadi karena adanya kandungan air yang lebih tinggi dibandingkan kontrol (KKK berkisar antara 45,29-45,88\%). Air tersebut berasal dari larutan bahan aditif yang dicampurkan ke dalam lateks. Dengan konsentrasi bahan aditif hanya 10\%, maka kandungan air dalam larutan bahan aditif mencapai 90\%. Dengan bertambahnya air dalam lateks akan berdampak semakin rendahnya KKK lateks karena air menjadi faktor pengenceran. Analisa KKK pada koagulum karet akan mempengaruhi proses pengeringan yang terkait dengan konsumsi energi. Koagulum yang mempunyai KKK lebih tinggi dapat dikeringkan lebih cepat dibandingkan koagulum dengan KKK rendah. Hal ini terjadi karena kandungan air yang harus dihilangkan lebih sedikit.

Pengeringan merupakan proses penting untuk mengurangi kandungan air bahan dan memastikan mutu produk yang konsisten ( $\mathrm{Ng}$ et al., 2015). Proses pengeringan yang cepat ini akan meningkatkan efisiensi biaya produksi.
Tham et al. (2014) dan Ekphon et al. (2013) menyatakan bahwa proses pengeringan merupakan salah satu proses yang memerlukan energi cukup besar dalam industri karet alam.

Dengan semakin rendahnya kandungan air dalam karet alam, maka waktu pengeringan menjadi lebih singkat sehingga energi yang diperlukan pun menjadi lebih rendah atau lebih efisien. Hasil penelitian Khongchana et al. (2007) menyatakan energi yang diperlukan untuk menguap kadar air dalam karet alam paling sedikit $26,09 \mathrm{MJ} / \mathrm{kg}$ air yang teruapkan.

\section{Plastisitas Karet}

Parameter mutu plastisitas karet alam yang diamati berupa nilai plastisitas awal (Po) dan indeks ketahanan plastisitas (PRI). Hasil analisa kedua parameter dapat dilihat pada Gambar 2 dan Gambar 3. Plastisitas awal (Po) adalah ukuran plastisitas karet yang secara tidak langsung memperkirakan panjangnya rantai polimer molekul karet atau berat molekul (BM) karet. PRI adalah suatu ukuran ketahanan karet terhadap pengusangan (oksidasi) pada suhu tinggi. Nilai PRI diukur dari besarnya keliatan karet mentah yang masih tertinggal apabila sampel tersebut dipanaskan selama 30 menit pada suhu $140{ }^{\circ} \mathrm{C}$. Nilai PRI merupakan persentase keliatan karet sesudah dipanaskan dibandingkan dengan keliatan sebelum dipanaskan dan ditentukan dengan alat Wallace Plastimeter. Nilai Po dan PRI merupakan parameter dasar untuk menentukan mutu karet (Achmadi et al., 2015). Semakin tinggi nilai PRI, maka semakin baik mutu karet (Montha et al., 2016).

Hasil analisa menunjukkan bahwa parameter mutu plastisitas karet alam, baik nilai Po (Gambar 2) maupun PRI (Gambar 3), secara signifikan dipengaruhi oleh perlakuan yang diberikan. Nilai Po semua karet alam yang ditambahkan aditif campuran hidrazin hidrat-ammonium sulfat dengan berbagai dosis penggunaan secara umum lebih tinggi dibandingkan kontrol. 
Nilai Po karet alam yang menggunakan bahan aditif campuran hidrazin hidrat dan ammonium sulfat sekitar 35,5-43,0. Angka ini mengindikasikan bahwa bahan aditif campuran hidrazin hidrat dan ammonium sulfat dengan berbagai dosis penggunaan mampu menghasilkan karet alam dengan Po yang tinggi.

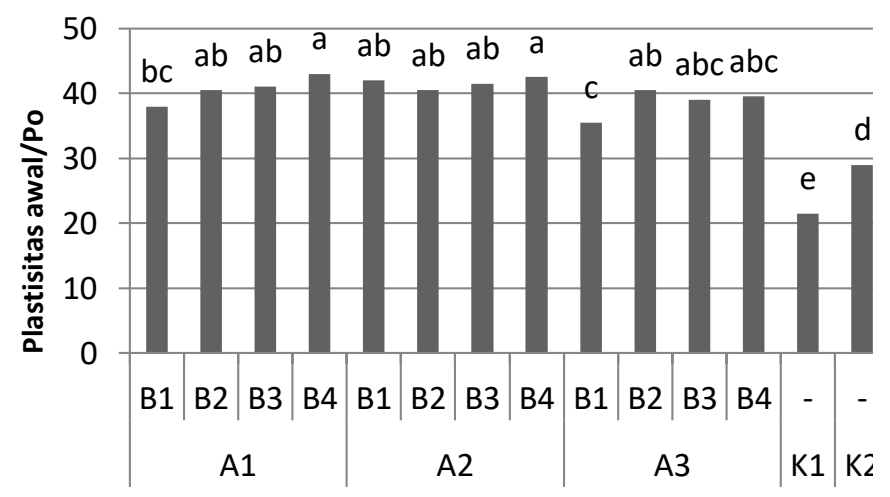

Perlakuan formula aditif dan dosis penggunaan

\section{Gambar 2. Plastisitas awal karet alam pada berbagai perlakuan}

Ket : angka-angka yang diikuti huruf yang sama pada setiap baris berarti tidak berbeda pada uji lanjutan Jarak Berganda Duncan (DMRT) pada tingkat kepercayaan 95\% (á $=0,05)$

Kemampuan tersebut lebih disebabkan adanya senyawa ammonium sulfat yang tidak menurunkan nilai Po. Hasil ini sesuai dengan penelitian Vachlepi dan Suwardin (2015a) yang membuktikan penggunaan garam ammonium salah satunya ammonium sulfat tidak menurunkan nilai Po karet alam. Dengan adanya ammonium sulfat mampu menutupi dampak penggunaan hidrazin yang terbukti dapat menurunkan nilai Po.

Nilai Po karet alam kontrol tanpa bahan aditif (K2) hanya 29,0 dan karet alam kontrol dengan bahan aditif HNS (K1) sekitar 21,5. Solichin dan Setiadi (1992) menyatakan bahwa pemberian HNS secara nyata menurunkan nilai Po. Berdasarkan hasil analisa ini diketahui bahwa nilai Po semua karet alam yang menggunakan bahan aditif campuran hidrazin hidrat dan ammonium sulfat memenuhi persyaratan SNI 06-19032000. Sedangkan karet alam kontrol, baik $\mathrm{K} 1$ maupun $\mathrm{K} 2$, belum memenuhi standar yang dipersyaratkan SNI 061903-2000. Pada SNI tersebut, karet alam ekspor untuk standar SIR 20 adalah minimal 30 (Tabel 2). Untuk meningkatkan nilai Po pada karet alam kontrol dapat dilakukan dengan cara penggantungan. Metode ini banyak digunakan pabrik karet remah dalam mengatasi mutu plastisitas yang rendah.

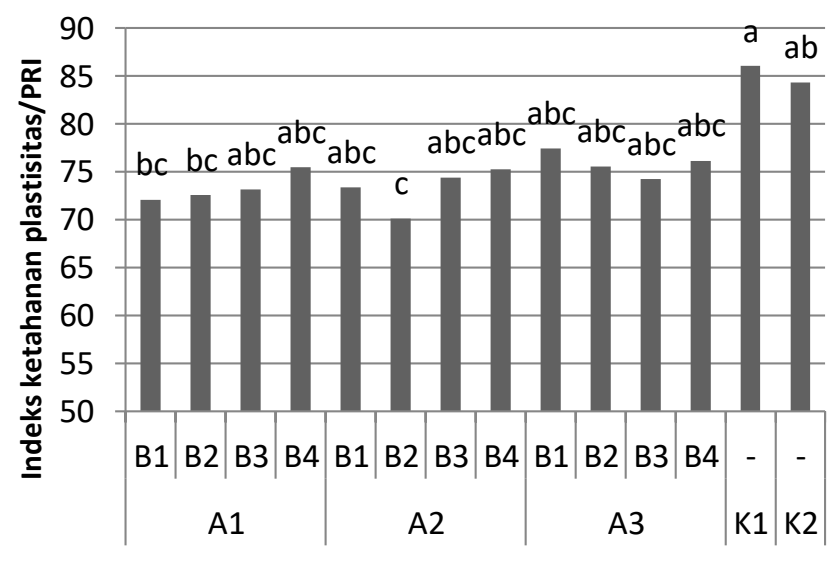

Perlakuan formula aditif dan dosis penggunaan

Gambar 3. Nilai PRI karet alam pada berbagai perlakuan

Ket : angka-angka yang diikuti huruf yang sama pada setiap baris berarti tidak berbeda pada uji lanjutan Jarak Berganda Duncan (DMRT) pada tingkat kepercayaan 95\% (á $=0,05)$

Seperti terlihat pada Gambar 3, hasil analisa PRI karet alam semua perlakuan secara umum memenuhi persyaratan mutu SNI 06-1903-2000. Nilai PRI karet alam semua perlakuan berkisar antara 70,2-86,1. Persyaratan minimal nilai PRI untuk karet alam SIR 20 adalah 50. Hasil ini membuktikan bahwa penggunaan bahan aditif campuran hidrazin hidrat dan ammonium sulfat tidak merusak mutu PRI karet alam. 


\section{Viskositas Mooney dan Indeks Kestabilan Viskositas Karet Alam}

Analisa parameter mutu viskositas yang dilakukan berupa nilai viskositas Mooney (Gambar 4) dan indeks kestabilan viskositas/SVI (Gambar 5). Parameter viskositas Mooney menggambarkan panjang rantai molekul karet. Parameter mutu ini memegang peranan penting dalam proses pencampuran ketika pembuatan kompon, baik untuk tingkat dispersi bahan-bahan kimia di dalam karet maupun energi yang diperlukan untuk penggilingan di mesin pencampur. Viskositas yang terlalu tinggi menyebabkan tingginya konsumsi daya mesin pemproses. Sebaliknya jika viskositasnya sangat rendah, menyebabkan rendahnya gaya geser pada pencampuran yang berakibat material cenderung beraglomerasi maka homogenitasnya rendah (Maspanger, 2008). Viskositas Mooney biasanya digunakan juga sebagai indikator teknologi untuk mengetahui karakterisasi partikel karet ditinjau dari kemampuannya saat pemprosesan lebih lanjut, termasuk pada saat pembuatan kompon (Zheleva, 2013).

Parameter SVI lebih menggambarkan perubahan nilai viskositas Mooney karet alam selama proses penyimpanan sebelum karet alam diproses lebih lanjut menjadi barang jadi karet. Nilai SVI ini menunjukkan seberapa stabil atau konstan viskositas karet alam selama proses penyimpanan dan pengangkutan.

Seperti terlihat pada Gambar 4 diketahui bahwa perlakuan yang diberikan memberikan pengaruh yang signifikan terhadap nilai viskositas Mooney. Nilai viskositas karet alam yang menggunakan bahan aditif campuran hidrazin hidrat-ammonium sulfat secara umum lebih tinggi dibandingkan kontrol. Nilai viskositas Mooney karet alam dengan perlakuan bahan aditif campuran hidrazin hidrat-ammonium sulfat sekitar 72-82. Sedangkan karet alam kontrol hanya mempunyai nilai viskositas Mooney sebesar 67 untuk HNS dan 59 untuk karet tanpa penambahan bahan aditif.

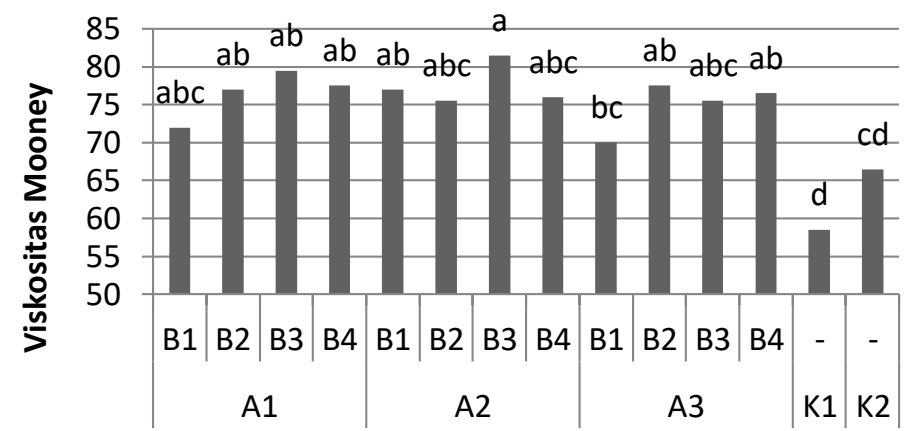

Perlakuan formula aditif dan dosis penggunaan

Gambar 4. Nilai viskositas Mooney karet alam pada berbagai perlakuan

Ket : angka-angka yang diikuti huruf yang sama pada setiap baris berarti tidak berbeda pada uji lanjutan Jarak Berganda Duncan (DMRT) pada tingkat kepercayaan $95 \%(\alpha=0,05)$

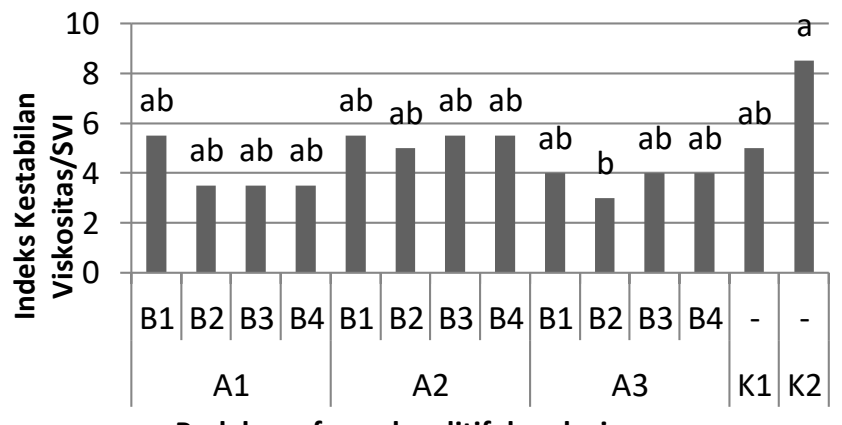

Perlakuan formula aditif dan dosis penggunaan

Gambar 5. Nilai SVI karet alam pada berbagai perlakuan

Ket : angka-angka yang diikuti huruf yang sama pada setiap baris berarti tidak berbeda pada uji lanjutan Jarak Berganda Duncan (DMRT) pada tingkat kepercayaan 95\% (ó $=0,05$ )

Berdasarkan Gambar 5, nilai indeks kestabilan viskositas (stability viscosity index/SVI) karet alam secara signifikan dipengaruhi oleh perlakuan penggunaan bahan aditif. Karet alam yang diberikan bahan aditif, baik campuran hidrazin hidrat-ammonium sulfat maupun HNS, umumnya mempunyai nilai SVI yang lebih rendah dibandingkan kontrol tanpa bahan aditif. Nilai indeks kestabilan viskositas karet alam dengan bahan aditif berkisar antara 
3-6, sementara itu kontrol tanpa bahan aditif nilai indeks kestabilan viskositasnya hanya 9. Hasil analisa tersebut mengindikasikan bahwa karet alam tanpa bahan aditif lebih tidak stabil dibandingkan dengan karet alam yang ditambahkan bahan aditif. Nilai viskositas karet alam tanpa bahan aditif (blanko) bisa mencapai 9 angka lebih tinggi dibandingkan viskositas awal yang hanya 67. Setelah dilakukan penyimpanan, viskositas Mooney karet alam tanpa aditif (blanko) dapat berubah menjadi 76.

Berdasarkan hasil analisa viskositas Mooney dan SVI, perlakuan $30 \%$ hidrazin hidrat dan $70 \%$ ammonium sulfat (A3) dengan berbagai dosis penggunaan mempunyai nilai SVI yang paling rendah dengan rata-rata sekitar 34 poin. Nilai viskositas Mooney dari karet alam tersebut berkisar antara 70-78. Dari kedua paramater mutu ini, perlakuan A3B1 merupakan perlakuan terbaik karena dengan dosis yang rendah (hanya 0,05\%) dapat menghasilkan karet alam yang memenuhi persyaratan sebagai SIR 20CV dengan grade CV-70 sesuai SNI 06-1903-2000 (Tabel 2).

\section{Kadar Zat Menguap}

Hasil analisa kadar zat menguap yang disajikan pada Gambar 6 menunjukkan bahwa kadar zat menguap karet alam secara umum tidak dipengaruhi oleh perlakuan penggunaan bahan aditif.

Hal ini terjadi karena dosis penggunaan bahan aditif sangat rendah, baik campuran hidrazin hidratammonium sulfat maupun HNS, yaitu berkisar antara 0,05\%-0,20\%.

Zat menguap di dalam karet sebagian besar terdiri dari uap air dan sisanya adalah zat-zat lain seperti serum yang mudah menguap pada suhu $100{ }^{\circ} \mathrm{C}$. Adanya zat yang mudah menguap didalam karet, selain dapat menyebabkan bau busuk, juga memudahkan tumbuhnya jamur yang dapat menimbulkan kesulitan pada waktu mencampurkan bahan-bahan kimia ke dalam karet pada waktu pembuatan kompon terutama untuk pencampuran karbon black pada suhu rendah (BSN, 2000). Kadar zat menguap tertinggi terdapat dari karet alam dengan perlakuan B1A3 sebesar 0,34\%. Sedangkan kadar zat menguap terendah diperoleh karet alam pada perlakuan A2B2 yaitu $0,21 \%$.

Hasil analisa kadar zat menguap semua karet alam secara umum memenuhi persyaratan mutu sebagai karet alam SIR 20CV dimana persyaratan kadar zat menguap dalam SNI 06-1903-2000 yaitu maksimum 0,80.

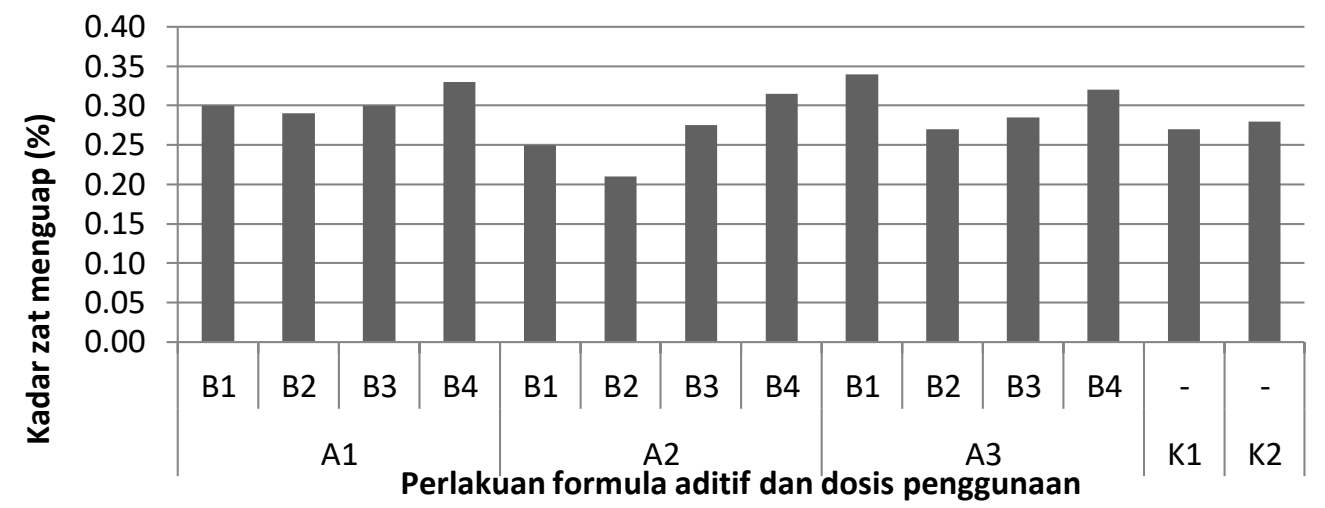

Gambar 6. Kadar zat menguap karet alam yang diberikan berbagai perlakuan bahan aditif dan dosis penggunaannya 


\section{Kadar Abu}

Semua perlakuan yang diberikan pada penelitian ini secara statistik tidak berpengaruh nyata terhadap kadar abu karet alam yang dihasilkan (Gambar 7). Hal ini terjadi karena bahan aditif yang digunakan berupa hidrazin hidrat dan ammonium sulfat bukan termasuk golongan senyawa anorganik yang dapat meningkatkan abu dalam karet alam. Hasil analisa menunjukkan bahwa kadar abu tertinggi diperoleh perlakuan A1B1 sebesar $0,50 \%$. Sedangkan kadar abu terendah terdapat pada karet alam perlakuan A2B2 sebesar 0,30\%.
Kadar abu semua perlakuan berasal dari lateks karet alam itu sendiri. George dan Jacob (2000) menyatakan bahwa total konsentrasi senyawa atau ion anorganik di dalam lateks segar adalah sekitar 0,50\%. Hasil analisa ini menunjukkan bahwa karet alam yang diproduksi menggunakan bahan aditif campuran hidrazin hidrat dan ammonium sulfat memenuhi persyaratan mutu SNI 06-1903-2000 sebagai karet alam SIR $20 \mathrm{CV}$ dimana kadar abu karet alam yang dihasilkan tidak lebih dari $1 \%$.

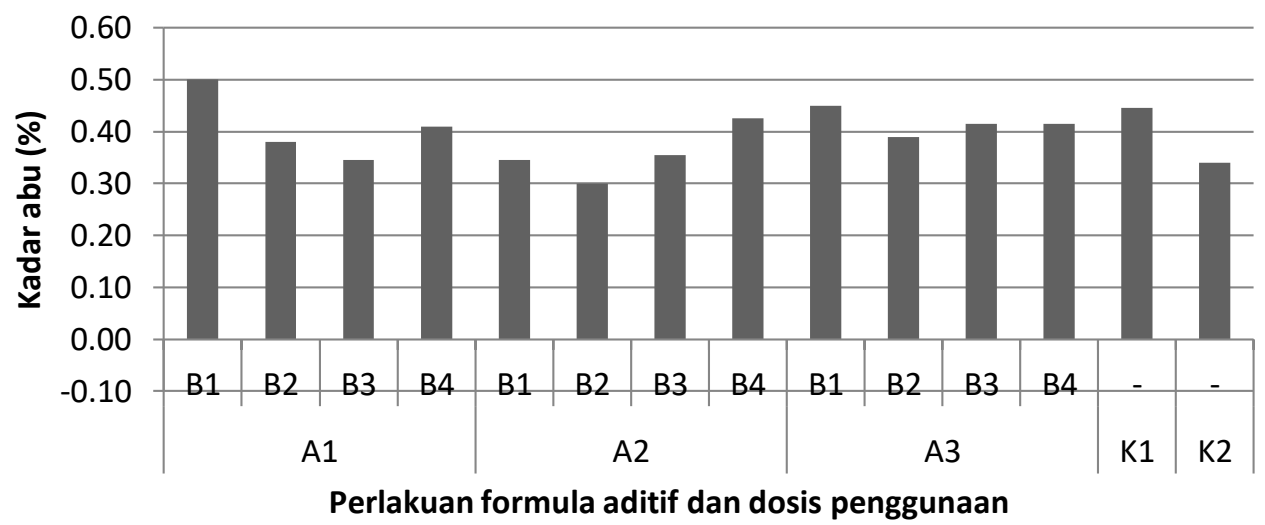

Gambar 7. Kadar abu karet alam pada berbagai perlakuan bahan aditif dan dosis penggunaannya

\section{KESIMPULAN}

Penggunaan bahan aditif campuran hidrazin hidrat dan ammonium sulfat secara signifikan hanya mempengaruhi parameter $\mathrm{pH}$ penggumpalan lateks, kadar karet kering, plastisitas, viskositas dan indeks kestabilan viskositas dari karet alam yang dihasilkan. Perlakuan terbaik dihasilkan perlakuan A3B1 yaitu perbandingan $30 \%$ hidrazin hidrat dan $70 \%$ ammonium sulfat dengan dosis $0,05 \%$. Perlakuan A3B1 dapat menghasilkan karet alam SIR 20CV dengan grade $\mathrm{CV}-70$ sesuai dengan $\mathrm{SNI}$ 06-1903-2000 tentang SIR.

\section{DAFTAR PUSTAKA}

Abednego, J. (1981). Pengetahuan Lateks dalam Pedoman Kursus Pengawasan Standard Indonesia
Rubber', in. Jakarta.

Achmadi, S.S., Cifriadi, A., dan Hidayah, M.N. (2015). Redistilat asap cair dari cangkang kelapa sawit dan aplikasinya sebagai koagulan karet alam. Jurnal Penelitian Karet, 33(2), 183-192.

Daik, R., Bidol, S. and Abdullah, I. (2007). Effect of molecular weight on the droplet size and rheological properties of liquid natural rubber emulsion. Malaysian Polymer Journal, 2(1), 29-38.

Direktorat Jenderal Perkebunan. (2015). Statistik perkebunan indonesia 20142016. Jakarta.

Ekphon, A., Ninchuewong, T., Tirawanichakul, S., and Tirawanichakul, Y. (2013). Drying model, shrinkage and energy consumption evaluation of air dried sheet rubber drying system for small enterprise.Advanced Materials Research, 622-623, pp. 1135-1139. doi: 
10.4028/www.scientific.net/AMR.622623.1135.

George, P.J and Jacob, C. (2000). Natural rubber agromanagement and crop processing. Rubber Research Institute of India.

Khongchana, P., Tirawanichakul, S., Tirawanichakul, Y., and Woravutthikhunchai, S. (2007). Effect of drying strategies on quality of STR 20 block rubbers. Journal of Agricultural Technology, 3(2), 151171.

Kumar, R.R., Hussain, S.N., and Philip, J. (2007). Measurement of dry rubber content of natural rubber latex with a capacitive transducer. Journal of Rubber Research, 10(1), 17-25.

Maspanger, D. (2008). Sifat fisik karet.In Makalah Kursus Teknologi Barang Jadi Karet. Bogor: Balai Penelitian Teknologi Karet, 75-76.

Montha, S., Suwandittakul, P., Poonsrisawat, A., Oungeun, P., and Kongkaew, C. (2016). Maillard reaction in natural rubber latex : characterization and physical properties of solid natural rubber. Hindawi Publishing Corporation, 2016, 1-6. http://dx.doi.org/10.1155/2016/78075 24

Ng, M. X., Tham, T. C., Ong, S. P., and Law, C. L. (2015). Drying kinetics of technical specified rubber. Information Processing in Agriculture. China Agricultural University, 2(1), 64-71.

doi: 10.1016/j.inpa.2015.05.001.

Rahman, N., Nugraheni, D.I., dan Febriyanti, L. (2002). Reaksi penjenuhan ikatan rangkap karet alam dalam fasa lateks pekat. Jurnal Penelitian Karet, 20(13), 1-10.

Sa, E.G., Rahman, N., Hidrogenasi, P., and Fasa, D. (2004). Pengaruh hidrogenasi dalam fasa lateks pada karet alam hevea brasiliensis. Jurnal Teknologi Industri Pertanian, 14(3), 80-86.

Solichin, M., dan Immanuel, V. (1991). Kajian pembuatan sit angin yang viskositasnya dimantapkan. Buletin Perkaretan, 7(2), 94-100.

Solichin, M., dan Setiadi, T. (1992). Pengaruh penambahan hidroksilamin netral sulfat dan lama pemeraman terhadap mutu lum mangkok. Buletin
Perkaretan, 8(1), 17-25.

Solichin, M. (1995). Pemantapan viskositas Mooney karet alam dengan natrium fenolat, natrium metabisulfit dan asetaldehida. Universitas Gadjah Mada.

Syarifa, L.F., Agustina, D.S., dan Nancy, C. (2013). Evaluasi pengolahan dan mutu bahan olah karet rakyat (bokar) di Sumatera Selatan. Jurnal Penelitian Karet, 31(2), 139-148.

Tham, T.C., Hii, C.L., Ong, S.P., Abdullah, L.C., and Law, C.L. (2014). Technical review on crumb rubber drying process and the potential of advanced drying technique. Agriculture and Agricultural Science Procedia. Elsevier Srl, 2, 26-32. doi: 10.1016/j.aaspro.2014.11.005.

Vachlepi, A., Suwardin, D., Purbaya, M., dan Hanifarianty, S. (2014). Application of hydrazine compound to produce constant viscosity rubber. Majalah Polimer Indonesia, 17(1), 1-5.

Vachlepi, A., dan Suwardin, D. (2015a). Karakteristik mutu karet alam SIR 20CV menggunakan bahan pemantap hidrazine pada suhu penyimpanan 60C. Jurnal Dinamika Penelitian Industri, 26(2), 85-94.

Vachlepi, A., dan Suwardin, D. (2015b). Penggunaan garam ammonium dalam produksi karet viskositas rendah dari lateks. Jurnal Penelitian Karet, 33(2), 193-202.

Vachlepi, A., dan Suwardin, D. (2016). Inhibisi korosi oleh hidroksilamin netral sulfat termodifikasi terhadap baja karbon. Jurnal Biopropal Industri, 7(2), 53-61.

Zheleva, D. (2013). An attempt for correlation between Mooney viscosity and rheological properties of filled rubber compounds. Journal of Chemical Technology and Metallurgy, 48(3), 241-246. 